\title{
Detection of Zika virus infection among asymptomatic pregnant women in the North of Peru
}

\author{
Claudia Weilg ${ }^{1,2 \dagger}{ }^{\dagger}$ Lucinda Troyes $^{3 \dagger}$, Zoila Villegas ${ }^{3}$, Wilmer Silva-Caso ${ }^{1,2}$, Fernando Mazulis ${ }^{1,2}$, Ammy Febres ${ }^{3}$, \\ Mario Troyes ${ }^{3}$, Miguel Angel Aguilar-Luis ${ }^{1,2,4^{*}}$ and Juana del Valle-Mendoza ${ }^{1,2^{*}}$
}

\begin{abstract}
Objective: To report an outbreak of ZIKV infection among asymptomatic pregnant women during 2016 in the city of Jaen, Cajamarca.

Results: Zika virus RNA was detected in 3.2\% $(n=36)$ of cases by RT-PCR. The mean age of patients positive for ZIKV infection was 29.6 years. 7 patients (19.4\%) infected with ZIKV were in their first-trimester of gestation, 13 (36.1\%) were in their second-trimester, and 16 (44\%) were in their third-trimester. All of the infected pregnant women were asymptomatic. ZIKV infection remains a major public health issue that calls for constant epidemiological surveillance. It can cause the congenital Zika virus syndrome in the newborns of infected mothers. The lack of molecular diagnostic methods in isolated localities and the similarity of symptoms to other arboviral infections, lead to an under-diagnosis of this disease in endemic areas.
\end{abstract}

Keywords: Zika virus, Pregnant women, Outbreak of Zika, Peru

\section{Introduction}

Zika virus (ZIKV) is an emergent arthropod-borne flavivirus associated with neurologic complications $[1,2]$. The first reports of human disease were described in Uganda and Tanzania during an outbreak in 1952 [3, 4]. On February 2016, the World Health Organization (WHO) declared Zika virus infection a Public Health Emergency of International Concern (PHEIC) due to the increasing number of cases and its associated complications. Currently, ZIKV is responsible for the ongoing outbreaks in the Caribbean and South America following the initial outbreak in Brazil [5].

The primary route of human ZIKV transmission is through the bite of mosquitoes Aedes aegypti and Aedes albopictus in tropical and temperate regions [5-7]. ZIKV

\footnotetext{
*Correspondence: ma23aguilar@gmail.com; juana.delvalle@upc.pe ${ }^{\dagger}$ Claudia Weilg and Lucinda Troyes contributed equally to this work 1 School of Medicine, Research and Innovation Centre of the Faculty of Health Sciences, Universidad Peruana de Ciencias Aplicadas, Av. San Marcos Cuadra 2, Chorrillos, Lima, Peru

Full list of author information is available at the end of the article
}

is also transmitted via transfusion of blood products, organ transplantation, laboratory exposure, sexual and, vertical maternal-fetal transmission [8-10]. After an incubation period of 2-14 days, patients develop an acute febrile syndrome associated with unspecific symptoms such as headaches, arthralgia, pruritic rash, nonpurulent conjunctivitis, myalgia, anorexia, asthenia, dysesthesia and retro-orbital pain $[11,12]$. Despite the low frequency of fatalities and hospitalization due to severe disease, ZIKV infection is associated with a high frequency of neurologic complications such as congenital microcephaly [13] and Guillain-Barre syndrome [14]. ZIKV infection during pregnancy can cause a set of fetal developmental complications, known as the congenital Zika virus syndrome [15]. Along with this syndrome, ZIKV is also associated with a higher rate of pregnancy loss and stillbirths among infected women $[16,17]$.

In Peru, the first ZIKV infection reported was a Venezuelan immigrant in January of 2016 [18, 19]. On March of 2016, a middle-aged woman from Lima, infected with ZIKV via sexual transmission, became 
the first autochthonous case in Peru reported by the Ministry of Health [20]. In the latest epidemiological update submitted by the PAHO in August of 2017, they describe a decreasing trend in the number of cases confirmed in South America since March of 2016 [18]. In contrast, some Peruvian regions such as Cajamarca, Loreto, Ica, Tumbes, La Libertad, and Lima, 8080 cases have reported with an increasing trend of confirmed cases since 2016 [21, 22]. To date, no pregnancy complications or congenital microcephaly have been attributed to a ZIKV infection in Peru, according to the Peruvian Ministry of Health [22]. This study aims to describe an outbreak of ZIKV infection in a newly endemic region of Peru among asymptomatic pregnant women and evaluate newborn congenital complications in the city of Cajamarca in 2016.

\section{Main text \\ Methods \\ Study setting}

This study was carried out between May and July of 2016 in the province of Jaen. This town has a population of 135,021, is located in the North of Peru in the city of Cajamarca and is endemic to other arboviral diseases such as dengue. Cajamarca is one the poorest regions in Peru, with a 56\% of its population living in poverty compared to the national average of 36\% [23]. Cajamarca is also one of the regions with a higher incidence of maternal deaths with 31 cases reported a year prior this study in 2015 [24].

Venous and urine samples of 1116 asymptomatic pregnant patients, were collected in the Regional Laboratory of the Jaen Medical Health Network as part of the pregnancy screening program. The inclusion criteria were pregnant patients with a current or recent history of residence in Jaen. Pregnant women with acute undifferentiated febrile illness with symptoms such as headaches, muscle pain, ocular and/or joint pain, rash, nausea, asthenia, anorexia, or any other symptom that could suggest an infection.

Patients positive to ZIKV were included in a microcephaly protocol with ultrasound evaluation upon diagnosis and every three thereafter. The cephalic perimeter of the newborn was measured at birth and at $24 \mathrm{~h}$. Microcephaly was defined as an occipitofrontal diameter greater than two standard deviations below the mean or less than the 3rd percentile based on standard growth charts for sex, age, and gestational age at birth [25]. Newborns were followed up 6 months later by a pediatric neurologist.

\section{Ethics statements}

Samples were collected following a written informed consent signed by all participants before enrollment or by the parents or respective guardians in the case of underage patients below 18 years of age. The study was approved by the Research Ethics Board of the Hospital Docente Regional de Cajamarca in Peru.

\section{Samples}

A venous blood sample was collected per patient by using Vacuette ${ }^{\circledR}$ EDTA blood collection tubes (Greiner Bio-One $\mathrm{GmbH}$, Frickenhausen, Germany) and these were stored at $4{ }^{\circ} \mathrm{C}$ until processing.

\section{RNA extraction}

The RNA was extracted from $200 \mu$ of blood samples using High Pure Kit Preparation template (Roche Diagnostics GmbH, Mannheim, Germany).

\section{Real-time RT-PCR assay for Detection ZIKV with taqman probe}

A one-step RT-PCR was performed as described by Alva et al. [26]. The primers and the probe used are the ones described by Faye et al. [27].

\section{Results}

1116 samples of pregnant women were studied from May to July 2016. None of the recruited samples were excluded from the data analysis due to exclusion criteria. Of all the samples, $3.2 \%(n=36)$ of cases were positive for ZIKV by RT-PCR.

Of the positive cases for infection by ZIKV confirmed by RT-PCR, the mean age of patients was 29.6 years and $8.3 \%(\mathrm{n}=3)$ were below 18 years of age. In relation to the gestational age of the infected mothers, 7 patients (19.4\%) were in the first trimester, 13 (36.1\%) were in the second trimester and $16(44 \%)$ were in their third trimester of pregnancy (Table 1).

All the ultrasound evaluations $(n=33)$ were negative for microcephaly, and the head circumference measured at birth and during the postnatal controls were within normal limits. According to the evaluation of normal growth and development of the newborns of the infected mothers, there was no anomaly found. Three infected pregnant women with a diagnosis during their third trimester were lost before the follow-up.

\section{Discussion}

Zika virus infection has emerged as a major public health issue in the Americas. The broad geographical range of the vector and the emerging complications of the ZIKV infection have made this flavivirus a growing 


\begin{tabular}{|c|c|c|}
\hline Characteristics & $\begin{array}{l}\text { Total samples, } \\
\mathrm{n}=1116(\%)\end{array}$ & $\begin{array}{l}\text { Zika virus } \\
\text { positive, } \\
n=36(\%)\end{array}$ \\
\hline \multicolumn{3}{|l|}{ Age (years) } \\
\hline$<18$ & $84(7.5)$ & $3(8.3)$ \\
\hline $18-35$ & $896(80.3)$ & $31(86.1)$ \\
\hline$>35$ & $136(12.2)$ & $2(5.6)$ \\
\hline Mean age & & 29.6 \\
\hline \multicolumn{3}{|l|}{ Place of residence } \\
\hline Jaén & $923(82.7)$ & $36.0(100)$ \\
\hline San Ignacio & $190(17.0)$ & $0(0)$ \\
\hline Cutervo & $3(0.3)$ & $0(0)$ \\
\hline \multicolumn{3}{|c|}{ Gestational age (weeks) } \\
\hline $1-12$ & $222(19.9)$ & $7(19.4)$ \\
\hline $13-27$ & $460(41.2)$ & $13(36.1)$ \\
\hline$>27$ & $434(38.9)$ & $16(44.4)$ \\
\hline
\end{tabular}

global concern that calls for constant epidemiological surveillance and a strategic response plan [28]. One of the target populations for the public health strategies are pregnant women because of the associated complications that ZIKV infection could have on them and their newborns [17]. Our findings show a prevalence of $3.2 \%(n=36)$ of ZIKV infection among the asymptomatic pregnant women population of Jaen in the region of Cajamarca, which is higher than the 31 confirmed cases of ZIKV in asymptomatic women during 2016 in Peru [22]. The mentioned findings may indicate that there is an underestimation of ZIKV infection that could be explained by the lack of sensitive and specific molecular diagnostic methods in isolated localities. Furthermore, the prevalence in this study highlights the importance of epidemiological surveillance of ZIKV infection in pregnant women that live in newly ZIKV endemic regions such as Jaen. These findings cannot be extrapolated to the ZIKV infection rates among pregnant women in other endemic regions of Peru because of the lack of similar molecular diagnostic studies in other Peruvian localities. In South America, the incidence of ZIKV peaked in February 2016 and subsequently showed a declining tendency with the exception of Ecuador [18, 29] Peruvian data showed an opposite trend that may be due to an underestimation of the prevalence during 2016 caused by the lack of a consolidated surveillance program.

Congenital ZIKV syndrome may include microcephaly, ventriculomegaly, intracranial calcifications, extra-axial fluid, decreased brain parenchymal volume, lissencephaly, cerebellar hypoplasia, delayed myelination and hypoplasia of the corpus callosum [30-32]. Furthermore, newborns of infected mothers can develop cardiac anomalies with septum defects [33], hearing loss [34], seizures due to the underlying brain malformations, neuromotor abnormalities such as spasticity and feeding difficulties [15, 35], ocular abnormalities [36] and can be born small for the gestational age [37].

The most plausible ZIKV pathogenesis hypothesis of neurological complications describe that placental colonization and injury following maternal infection leads to the transmission of the virus to the fetal brain [38-40], where ZIKV preferentially infects neural progenitor cells [41]. As a result, this arbovirus disrupts neuronal growth, migration, proliferation, and differentiation, thus causing thinning of the cortex, macroscopic signs of microcephaly and impairment of normal brain development in the fetus [42]. This hypothesis also suggests the possibility that the placental inflammatory process contributes to the development of mentioned neurological complications [43].

The maternal age is also strongly associated with different pregnancy outcomes [44]. The risk of having a child with a congenital anomaly increases with advanced maternal age [45, 46], and it is not always related to the recognized increase in aneuploidy rate [47]. The US National Birth Defects Prevention Study found that newborns of women older than 40 years old had an increased risk of cardiac defects, craniosynostosis, esophageal atresia and hypospadias [47]. Also, studies consistently report that women older than 35 years old have a significantly increased risk of spontaneous abortion [48] and stillbirth compared to younger women [49]. ZIKV infection of pregnant women can also cause pregnancy losses and congenital malformations such as cardiac defects [33] and craniosynostosis [50], which may cause bias when estimating the risk of congenital ZIKV syndrome among women older than 35 years old. In our study, the mean age of infected pregnant women was 29.6 years and only $5.6 \%(\mathrm{n}=2)$ were older than 35 years.

The risk of vertical transmission and congenital ZIKV syndrome exists for both symptomatic and asymptomatic mothers $[51,52]$. It is important to mention that only $20 \%$ of the patients positive for ZIKV infection are symptomatic [53,54], which is why international guidelines recommend health care providers to screen all pregnant women for possible exposure to ZIKV at each prenatal visit, and to test those with ZIKV exposure risk three times during pregnancy even if they are asymptomatic [55].

The frequency of birth defects resulting from vertical transmission of ZIKV is not well established [56]. However, the risk of developing the congenital ZIKV syndrome is higher during the first and second trimester, 
even though severe fetal or newborn sequelae can also occur within the third-trimester infection [57, 58]. A prospective study in Brazil found that adverse outcomes were reported in 55\% of pregnancies after first-trimester maternal infection, $52 \%$ after second-trimester maternal infection, and $29 \%$ after third-trimester maternal infection [17]. Our study found that most of the infected pregnant women $(44 \%, n=16)$ got ZIKV infection during the third trimester and that none of the newborns developed microcephaly. These findings are similar to those published by the Peruvian National Epidemiological Center for Control and Prevention of Diseases [59] and can explain why there are no reported cases of congenital ZIKV syndrome in Peru yet. Nonetheless, $19.4 \%(n=7)$ and $36.1 \%(n=13)$ of pregnant women were infected during their first and second trimester, respectively. This fact highlights the importance of prenatal ultrasonography to evaluate fetal abnormalities consistent with congenital ZIKV syndrome [60, 61], and the need of careful clinical evaluation of these infants in ruling out microcephaly, ocular abnormalities, hearing loss, neurologic and positional abnormalities, craniofacial disproportion or cardiac defects [62].

In conclusion, the disease caused by ZIKV is an emerging infection that remains a major public health issue in South America due to their endemicity in isolated localities. This study reports the first molecularly confirmed outbreak in the region of Cajamarca in Peru among asymptomatic pregnant women and describes a higher frequency of infection in comparison to the national surveillance report. The unavailability of molecular diagnostic methods in isolated localities and the similarity of symptoms to other arboviruses leads to an under-diagnosis of this infection in arboviral endemic regions therefore, it is molecular diagnosis of ZIKV infection in pregnancy screening programs to evaluate and measure the impact of fetal anomalies associated with this virus, especially amongst asymptomatic patients in endemic regions.

\section{Limitations}

This study has two main limitations. First, the followup evaluation of the infant carried out by a pediatric neurologist, only occurred at 6 months of age. Second, there wasn't a follow up protocol looking for other ZIKV associated malformations for the newborns of infected mothers.

\section{Abbreviations}

ZIKV: Zika virus; RT-PCR: reverse transcription-polymerase chain reaction; RNA: ribonucleic acid; bp: base pairs.

\section{Authors' contributions}

JdVM LT and ZV designed the study protocol. CW, WS, FM, MAAL performed the RT-PCR and data analysis. JdVM and MAAL are responsible for obtaining funding and laboratory work supervision. ZV, LT, MT and AF was responsible for the clinical assessment, samples collection and database completion. $J \mathrm{dVM}, \mathrm{WS}$, FM and CW drafted the manuscript. All authors critically revised the manuscript for intellectual content. All authors read and approved the final manuscript.

\section{Author details \\ ${ }^{1}$ School of Medicine, Research and Innovation Centre of the Faculty of Health Sciences, Universidad Peruana de Ciencias Aplicadas, Av. San Marcos Cuadra 2, Chorrillos, Lima, Peru. ${ }^{2}$ Laboratorio de Biología Molecular, Instituto de Investigación Nutricional, Lima, Peru. ${ }^{3}$ Dirección Subregional de Salud de Jaén, Ministerio de Salud, Cajamarca, Peru. ${ }^{4}$ Instituto de Investigación de Enfermedades Infecciosas, Lima, Peru.}

\section{Acknowledgements}

We thank to the staff of the health network from Jaen, Cajamarca, Peru. We thank Brandy Russell at the Centers for Disease Control and Prevention (CDC, Fort Collins, CO, USA) provided positive controls for ZIKV.

\section{Competing interests}

The authors declare that they have no competing interests.

\section{Availability of data and materials}

Abstraction format used in the study and dataset are available and accessible from corresponding author upon request in the link: https://figshare.com/artic les/Dataset_Zika_Jaen_2018/5797212.

\section{Consent to publish}

Not applicable.

\section{Ethics approval and consent to participate}

This study has been approved by two independent Ethics Committees from Hospital Regional Docente de Cajamarca. All samples were analyzed after a written informed consent signed by all participants before enrollment or by the parents or children's caregivers in the case of underage patients below 18 years of age.

\section{Funding}

This work was supported by Programa Nacional de Innovación para la Competitividad y Productividad (Innóvate Perú), under the Contract 116-PNICPPIAP-2015 and Cienciactiva of CONCYTEC under the Contract 164-2016-FONDECYT. The funders had no role in study design, data collection and analysis, decision to publish, or preparation of the manuscript.

\section{Publisher's Note}

Springer Nature remains neutral with regard to jurisdictional claims in published maps and institutional affiliations.

Received: 19 January 2018 Accepted: 3 May 2018

Published online: 18 May 2018

\section{References}

1. Petersen $L R$, Jamieson DJ, Powers AM, Honein MA. Zika virus. N Engl J Med. 2016;374:1552.

2. Baud D, Gubler DJ, Schaub B, et al. An update on Zika virus infection. Lancet. 2017:390:2099.

3. Sirohi $D$, Chen $Z$, Sun L, et al. The 3.8 A resolution cryo-EM structure of Zika virus. Science. 2016:352:467.

4. The history of Zika virus. World Health Organization. 2018. http://www. who.int/emergencies/zika-virus/timeline/en/. Accessed 10 Apr 2018.

5. Heukelbach J, Alencar C, Kelvin A, De Oliveira W, de Góes Pamplona, Cavalcanti L. Zika virus outbreak in Brazil. J Infect Dev Ctries. 2016;10(02):116. 
6. Ioos S, Mallet HP, Goffart IL, Gauthier V, Cardoso T, Herida M. Current Zika virus epidemiology and recent epidemics. Medecine et Maladies Infectieuses. 2014;44:302-7.

7. Guerbois M, Fernandez-Salas I, Azar SR, et al. Outbreak of zika virus infection, Chiapas State, Mexico, 2015, and first confirmed transmission by Aedes aegypti mosquitoes in the Americas. J Infect Dis. 2016;214:1349.

8. Musso D, Nhan T, Robin E, et al. Potential for Zika virus transmission through blood transfusion demonstrated during an outbreak in French Polynesia, November 2013 to February 2014. Euro Surveill. 2013;2014:19.

9. Russell K, Hills SL, Oster AM, et al. Male-to-female sexual transmission of Zika virus-United States, January to April 2016. Clin Infect Dis. 2017:64:211.

10. Zika virus: Transmission. CDC. 2018. http://www.cdc.gov/zika/transmissi on/index.html. Accessed 10 Apr 2018.

11. Brasil P, Calvet GA, Siqueira AM, et al. Zika virus outbreak in Rio de Janeiro, Brazil: clinical characterization, epidemiological and virological aspects. PLoS Negl Trop Dis. 2016;10:e0004636.

12. Chen L, Hafeez F, Curry CL, Elgart G. Cutaneous Eruption in a US woman with locally acquired Zika virus infection. N Engl J Med. 2017;376:400.

13. Rasmussen SA, Jamieson DJ, Honein MA, Petersen LR. Zika virus and birth defects-reviewing the evidence for causality. N Engl J Med. 2016;374:1981.

14. Dos Santos T, Rodriguez A, Almiron M, et al. Zika virus and the GuillainBarré syndrome-case series from seven countries. N Engl J Med. 2016:375:1598

15. Miranda-Filho Dde B, Martelli CM, Ximenes RA, et al. Initial description of the presumed congenital Zika syndrome. Am J Public Health. 2016;106:598.

16. van der Eijk AA, van Genderen PJ, Verdijk RM, et al. Miscarriage associated with Zika virus infection. N Engl J Med. 2016;375:1002.

17. Brasil P, Pereira JP Jr, Moreira ME, et al. Zika virus infection in pregnant women in Rio de Janeiro. N Engl J Med. 2016;375:2321.

18. Sanchez J. PAHO WHO | Regional Zika Epidemiological Update (Americas) August 25, 2017. Pan American Health Organization/World Health Organization. 2017. http://www.paho.org/hq/index.php?option=com_conte nt\&view=article\&id =11599\%3Aregional-zika-epidemiological-updat e-americas\&ltemid=41691. Accessed 14 Nov 2017

19. Salud M. MINSA_Ministerio de Salud del Peru. Minsa.gob.pe. 2017. http://www.minsa.gob.pe/index.asp?op $=51 \&$ nota $=17201$. Accessed 14 Nov 2017.

20. Infección por el virus de Zika—Perú. Organización Mundial de la Salud. 2017. http://www.who.int/csr/don/21-april-2016-zika-peru/es/. Accessed 14 Nov 2017.

21. BOLETÍN EPIDEMIOLÓGICO DEL PERÚ-S28. Centro Nacional de Epidemiología. 2017. http://www.dge.gob.pe/portal/docs/vigilancia/bolet ines/2017/38.pdf. Accessed 14 Nov 2017

22. Sala Situacional_Zika. Centro Nacional de Epidemiología. 2017. http:// www.dge.gob.pe/portal/docs/vigilancia/sala/2017/SE42/zika.pdf. Accessed 14 Nov 2017.

23. Población en situación de pobreza por departmento. inei.gob.pe. 2018. https://www.inei.gob.pe/media/MenuRecursivo/indices_tematicos/cd4 xlsx. Accessed 4 Apr 2018.

24. Sala Situacional-Muerte Materna. Centro Nacional de Epidemiología. http://www.dge.gob.pe/portal/docs/vigilancia/sala/2018/SE12/mmate rna.pdf. Accessed 5 Apr 2017.

25. Villar J, Ismail L, Victora C, Ohuma E, Bertino E, Altman D, et al. International standards for newborn weight, length, and head circumference by gestational age and sex: the Newborn Cross-sectional study of the INTERGROWTH-21st project. Lancet. 2014;384(9946):857-68.

26. Alva-Urcia C, Aguilar-Luis M, Palomares-Reyes C, Silva-Caso W, SuarezOgnio L, Weilg P, Manrique C, Vasquez-Achaya F, del Valle L, del Valle-Mendoza J. Emerging and reemerging arboviruses: a new threat in Eastern Peru. PLoS ONE. 2017;12(11):e0187897.

27. Faye O, Faye O, Diallo D, Diallo M, Weidmann M, Sall AA. Quantitative real-time PCR detection of Zika virus and evaluation with field-caught mosquitoes. Virol J. 2013;10:311.

28. Aziz H, Zia A, Anwer A, et al. Zika virus: global health challenge, threat and current situation. J Med Virol. 2017:89:943-51.

29. Hills S, Fischer M, Petersen L. Epidemiology of Zika virus infection. J Infect Dis. 2017;216(suppl_10):S868-74.
30. Soares de Oliveira-Szejnfeld P, Levine D, Melo AS, et al. Congenital brain abnormalities and Zika virus: what the radiologist can expect to see prenatally and postnatally. Radiology. 2016;281:203.

31. Hazin AN, Poretti A, Cavalcanti Souza Cruz D Di, et al. Computed tomographic findings in microcephaly associated with Zika virus. N Engl J Med. 2016;374:2193.

32. Besnard M, Eyrolle-Guignot D, Guillemette-Artur P, et al. Congenital cerebral malformations and dysfunction in fetuses and newborns following the 2013 to 2014 Zika virus epidemic in French Polynesia. Euro Surveill. 2016. https://doi.org/10.2807/1560-7917.ES.2016.21.13.30181.

33. Cavalcanti DD, Alves LV, Furtado GJ, et al. Echocardiographic findings in infants with presumed congenital Zika syndrome: retrospective case series study. PLOS ONE. 2017;12:e0175065

34. Leal MC, Muniz LF, Ferreira TS, et al. hearing loss in infants with microcephaly and evidence of congenital Zika Virus infection-Brazil, November 2015-May 2016. MMWR Morb Mortal Wkly Rep. 2016;65:917.

35. França GV, Schuler-Faccini L, Oliveira WK, et al. Congenital Zika virus syndrome in Brazil: a case series of the first 1501 live births with complete investigation. Lancet. 2016;388:891.

36. de Paula Freitas B, de Oliveira Dias JR, Prazeres J, et al. Ocular findings in infants with microcephaly associated with presumed Zika virus congenital infection in Salvador, Brazil. JAMA Ophthalmol. 2016;134:529-35.

37. Meneses JDA, Ishigami AC, de Mello LM, et al. Lessons learned at the epicenter of Brazil's Congenital Zika epidemic: evidence from 87 confirmed cases. Clin Infect Dis. 2017;64:1302.

38. Tabata T, Petitt M, Puerta-Guardo H, et al. Zika virus targets different primary human placental cells, suggesting two routes for vertical transmission. Cell Host Microbe. 2016;20:155.

39. Jurado KA, Simoni MK, Tang Z, et al. Zika virus productively infects primary human placenta-specific macrophages. JCI Insight. 2016;1:e88461.

40. Garcez PP, Loiola EC, Madeiro da Costa R, et al. Zika virus impairs growth in human neurospheres and brain organoids. Science. 2016;352:816.

41. Klase ZA, Khakhina S, Schneider AB, et al. Zika fetal neuropathogenesis: etiology of a viral syndrome. PLoS Negl Trop Dis. 2016;10:e0004877.

42. Mlakar J, Korva M, Tul N, et al. Zika virus associated with microcephaly. N Engl J Med. 2016;374:951.

43. Hajra A, Bandyopadhyay D, Heise LR, et al. Zika and pregnancy: a comprehensive review. Am J Reprod Immunol. 2017. https://doi.org/10.1111/ aji.12607

44. Cleary-Goldman J, Malone FD, Vidaver J, et al. Impact of maternal age on obstetric outcome. Obstet Gynecol. 2005;105:983.

45. Hollier LM, Leveno KJ, Kelly MA, et al. Maternal age and malformations in singleton births. Obstet Gynecol. 2000;96:701.

46. Reefhuis J, Honein MA. Maternal age and non-chromosomal birth defects, Atlanta-1968-2000: teenager or thirty-something, who is at risk? Birth Defects Res A Clin Mol Teratol. 2004;70:572

47. Gill SK, Broussard C, Devine O, et al. Association between maternal age and birth defects of unknown etiology: United States, 1997-2007. Birth Defects Res A Clin Mol Teratol. 2012;94:1010.

48. Nybo Andersen AM, Wohlfahrt J, Christens P, et al. Maternal age and fetal loss: population based register linkage study. BMJ. 2000;320:1708

49. Flenady V, Koopmans L, Middleton P, et al. Major risk factors for stillbirth in high-income countries: a systematic review and meta-analysis. Lancet. 2011;377:1331

50. de Aragao MFV, van der Linden V, Brainer-Lima AM, et al. Clinical features and neuroimaging (CT and MRI) findings in presumed Zika virus related congenital infection and microcephaly: retrospective case series study. BMJ. 2016:353:1901.

51. Besnard M, Lastere S, Teissier A, et al. Evidence of perinatal transmission of Zika virus, French Polynesia, December 2013 and February 2014. Euro Surveill. 2014;19:20751.

52. Shapiro-Mendoza CK, Rice ME, Galang RR, et al. Pregnancy outcomes after maternal Zika virus infection during pregnancy-US Territories, January 1, 2016-April 25, 2017. MMWR Morb Mortal Wkly Rep. 2017;66:615.

53. Zhang Q, Sun K, Chinazzi M, Pastore y Piontti A, Dean N, Rojas $D$, et al. Spread of Zika virus in the Americas. Proc Natl Acad Sci. 2017;114(22):E4334-43.

54. Practice advisory interim guidance for care of obstetric patients during a Zika virus outbreak. Reproductive counseling. American College of Obstetricians and Gynecologists. 2017. http://www.acog.org/About -ACOG/News-Room/Practice-Advisories/Practice-Advisory-Interim-Guida 
nce-for-Care-of-Obstetric-Patients-During-a-Zika-Virus-Outbreak\#couns eling. Accessed 15 Nov 2017.

55. Oduyebo T, Polen KD, Walke HT, et al. Update: Interim guidance for health care providers caring for pregnant women with possible Zika virus exposure-United States (including U.S. territories), July 2017. MMWR. 2017;66:1.

56. Platt D, Miner J. Consequences of congenital Zika virus infection. Curr Opin Virol. 2017;27:1-7.

57. Pacheco O, Beltrán M, Nelson CA, et al. Zika Virus disease in Colombiapreliminary report. N Engl J Med. 2016. https://doi.org/10.1056/NEJMo a1604037.

58. Cauchemez S, Besnard M, Bompard P, et al. Association between Zika virus and microcephaly in French Polynesia, 2013-2015: a retrospective study. Lancet. 2016;387:2125.
59. Sala Situacional Semana 36. dge.gob.pe. 2017. http://www.dge.gob.pe/ portal/docs/vigilancia/sala/2017/salaSE36.zip. Accessed 15 Nov 2017.

60. Baud D, Van Mieghem T, Musso D, et al. Clinical management of pregnant women exposed to Zika virus. Lancet Infect Dis. 2016;16:523.

61. Oliveira Melo AS, Malinger G, Ximenes R, et al. Zika virus intrauterine infection causes fetal brain abnormality and microcephaly: tip of the iceberg? Ultrasound Obstet Gynecol. 2016:47:6.

62. Russell $K$, Oliver SE, Lewis $L$, et al. Update: interim guidance for the evaluation and management of infants with possible congenital Zika virus infection — United States, August 2016. MMWR Morb Mortal Wkly Rep. 2016;65:870-8
Ready to submit your research? Choose BMC and benefit from:

- fast, convenient online submission

- thorough peer review by experienced researchers in your field

- rapid publication on acceptance

- support for research data, including large and complex data types

- gold Open Access which fosters wider collaboration and increased citations

- maximum visibility for your research: over $100 \mathrm{M}$ website views per year

At BMC, research is always in progress.

Learn more biomedcentral.com/submissions 